\title{
Psychological Capital Impacts on Safety Behavior of Contractor Workers using the SEM Method
}

\section{Dampak Psychological Capital terhadap Safety Behavior pada Pekerja Kontraktor dengan Metode SEM}

\author{
Heppy Ridhatul Aula ${ }^{1}$, Dewi Kurniasih ${ }^{2}$, Farizi Rachman ${ }^{3}$ \\ ${ }^{1,2}$ Study Program of Safety and Health Engineering, Department of Marine Engineering \\ ${ }^{3}$ Study Program of Design and Manufacture Engineering, Department of Marine Engineering \\ Shipbuilding Institute of Polytechnic Surabaya \\ Teknik Kimia Street ITS Campus, Surabaya, East Java 60111, Indonesia
}

\begin{abstract}
Introduction: A steam power plant company is an electric energy production company, utilizing main energy sources such as coal, biomass, and other energies that are related to production process. This company is a big industry that operates 24 hours and have many various steps of production process. It is also supported by a variety of high-risk system equipment such as confined spaces, working at height, hot work, ergonomics, mechanics, and others. This type of work can lead to workers' unsafe conditions and unsafe acts. One of the causes is the psychological aspects of workers, namely the lack of workers' awareness and understanding in implementing occupational safety aspects. Workers' psychology in this study is Psychological Capital (PsyCap) with self-efficacy, hope, optimism, and resilience dimensions. This study aims to analyze PsyCap impacts on safety behavior of contractor workers. Methods: this study was an observational analytic research using cross-sectional approach. The population was all workers in a steam power plant company in units $7 \& 8$, totalling 400 contractors. This study was conducted by distributing questionnaires to 101 respondents of contractor workers. The questionnaires consisted of items about self-efficacy, hope, optimism, and resilience dimension of PsyCap and safety compliance and safety participation dimension of safety behavior. The analysis used a Structural Equational Modeling (SEM) method and AMOS software. Results: PsyCap dimensions that impacted on safety behavior was optimism. Conclusion: optimism dimension was the factor that had the strongest impact on safety behavior especially workers' safety compliance. Meanwhile, other PsyCap dimensions which did not have not impact on safety behavior were safety compliance and safety participation dimensions.
\end{abstract}

Keywords: contractor worker, psychological capital, safety behavior, steam power plant company, structural equational modelling

\section{ABSTRAK}

Pendahuluan: Perusahaan pembangkit listrik tenaga uap merupakan perusahaan produksi energi listrik dengan memanfaatkan sumber energi utama berupa batubara, biomasa, dan energi-energi lain yang berkaitan dengan proses produksi. Perusahaan ini merupakan industri besar yang beroperasi 24 jam dengan berbagai tahap proses produksi yang ditunjang berbagai peralatan sistem risiko bahaya tinggi seperti ruang terbatas, pekerjaan pada ketinggian, pekerjaan panas, ergonomi, mekanik, dan lain-lain. Pekerjaan tersebut dapat memicu terjadinya kondisi tidak aman dan perilaku tidak aman pada pekerja. Salah satu penyebabnya adalah aspek psikologi pekerja, yaitu kurangnya kesadaran dan pemahaman pekerja dalam pelaksanaan aspek keselamatan kerja. Psikologi pekerja dalam penelitian ini yaitu Psychological Capital (PsyCap) dengan dimensi efikasi diri, harapan, optimis, dan ketahanan. Penelitian ini bertujuan menganalisis dampak PsyCap terhadap perilaku keselamatan pekerja kontraktor. Metode: Penelitian ini merupakan penelitian observational analitis dengan pendekatan cross sectional. Populasi seluruh pekerja di perusahaan pembangkit listrik unit $7 \& 8$ berjumlah 400 kontraktor. Penelitian dilakukan dengan penyebaran kuesioner terhadap 101 responden pekerja kontraktor. Kuesioner terdiri dari dimensi efikasi diri, harapan, optimis dan ketahanan dari PsyCap dan dimensi kepatuhan keselamatan dan partisipasi keselamatan dari dimensi perilaku keselamatan. Analisis menggunakan metode Structural Equational Modelling (SEM) menggunakan software AMOS. Hasil: Dimensi Psycap yang memiliki dampak terhadap perilaku keselamatan adalah optimis. Simpulan: Dimensi optimis merupakan faktor yang memiliki dampak paling kuat terhadap perilaku keselamatan khususnya kepatuhan keselamatan pekerja. Sedangkan dimensi Psycap lainnya tidak memiliki dampak terhadap perilaku keselamatan baik dimensi kepatuhan keselamatan maupun partisipasi keselamatan.

Kata kunci: pekerja kontraktor, perilaku keselamatan, perusahaan pembangkit listrik tenaga uap, psychological capital, structural equational modelling

(C2021 IJOSH All right reserved. Open access under CC BY NC-SA license doi:10.20473/ijosh.v10i2.2021.180-187 Received August 11, 2020, received in revised form October 20, 2020, Accepted March 24, 2021, Published: August 2021 


\section{Corresponding Author:}

Heppy Ridhatul Aula

Email: heppyaula@gmail.com

Telephone: +6289674360231

\section{INTRODUCTION}

Occupational accident is defined as a situation, occurred in the work time, which leads to physical or mental harm (Mehrdad et al., 2014). Work accident according to Heinrich's Domino theory, $88 \%$ work accident caused by unsafe act factors, $10 \%$ caused by unsafe conditions factors, and $2 \%$ caused by unpredictable factors (OHS Body of Knowledge, 2012). Further investigation has found that 80 $90 \%$ of the accidents were caused by human errors and unsafe behaviors (Shi et al., 2019). Unsafe behavior based of Luckyta \& Partiwi (2012) is a type of behavior that leads to accidents such as working without regard on safety, work operating on dangerous speed, using nonstandard equipment, rudely act, lack of knowledge, disability or disturbed emotional state. The best way to reduce unsafe behavior to generate the desire changes only focus on safety behavior.

He et al. (2019) safety behavior is the safety related action performed by individuals in an organization. Physical and psychological factors may influence the cognitive mechanism of safety behavior. According to Griffin and $\mathrm{Hu}$ (2013) there are two distinct forms of safety behavior, namely safety participation and safety compliance. Safety participation refers to employee's voluntary participation in safety activities, which aims to contribute to the development of a supportive safety environment. Example of safety participation are participation in safety meeting, raising safety concern, and promoting safety programs in organization. Safety compliance on the other hand refers to the behaviors that are about engaging in core safety task, such as compliance with the organization's safety rules and regulations, and following safety procedures. Based on Social Cognitive Theory in Bandura's research in Wang, Wang and Xia (2018) shows that not individual's behavior not only influenced by the environment, but also can be influenced by psychological perception and depends on individual characteristic. Behavior is influenced by individual's psychological capital (PsyCap) which influenced by the organizational environment.

Psychological Capital or PsyCap is a condition or strength that develops during a person's growth and thrived. These strengths can be assessed, developed, and utilized to improve performance. There are three perspectives of Psycap. First, it focuses on individual characteristics resulting from interactions between the environment and one's offspring which have been described using a fivefactor model, includes neuroticism, extraversion, openness, conformity, and conscientiousness. Second, it shows PsyCap is a psychological state that can be used to predict and improve personal performance. Third, it Suggests that PsyCap is an integrated psychological ability and consist of individual characteristics and psychological states.

According to Luthans, Luthans and Chaffin (2019) PsyCap is an individual's psychological capital state of development and is characterized by: (1) having confidence (self-efficacy) to take on and put in the necessary effort to succeed at challenging tasks; (2) making a positive attribution (optimism) about succeeding now and in the future; (3) persevering toward goals and, when necessary, redirecting paths to goals (hope) in order to succeed; and (4) when beset by problems and aversity, sustaining and bouncing back and even beyond (resiliency) to attain success. Based on PsyCap theory Wang, Wang and Xia (2018) individuals with high levels of PsyCap tend to have positive attitudes and behaviors at work. Study of He et al. (2019) shows that PsyCap not only help the workers to complete the job on their role, but also to motivates them to take organizational behaviors. Health psychological state would be beneficial to further develop safety performance.

The impact result from investing, developing, anda managing the entire PsyCap on performance and the result of attitude is expected of individual psychological capacities that composing it bigger. For example, how the PsyCap factors interact is that hopeful people who have an intermediary and a pathway to achieve their goals are more motivated and able to overcome adversity and thus become more resilient. Self-efficacy will be able to transfer and apply their hope, optimism, and resilience to specific tasks in specific areas of their lives. Resilient people are adept at exploiting the adaptation mechanisms needed for a realistic, flexible optimist. PsyCap's self-efficacy, hope and resilience can alter the contribution of an optimistic explanation style through internal perceptions of control. This only represents the number of positive results that might result from interactions between the PsyCap factors.

Case study this research in the steam power plant company. Activities of the production, the 


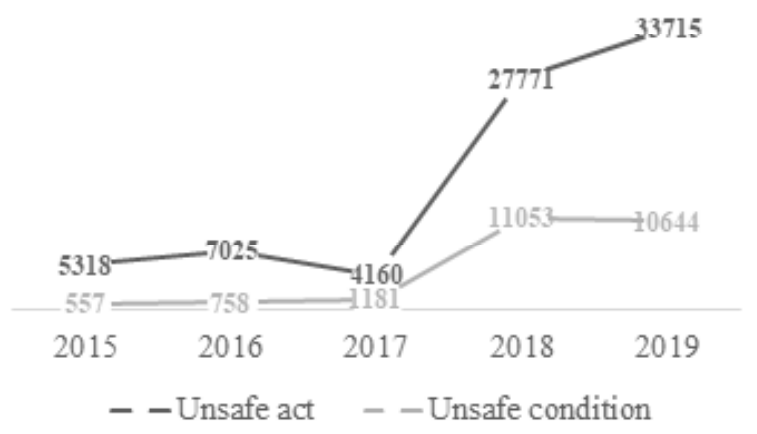

Figure 1. The company's site safety statistics

company operates on 24 hours at the day. Based on company's site safety statistic for three years, 2017 until 2019 there are eight accident cases and once accident is fatality, while seven others caused by unsafe act. The most accident cases caused by unsafe act, so from this necessary to analysis the factor that influences on safety behavior in the workplace and involvement of contractor workers in the power plant. Safety behavior in the workplace and employee involvement in work safety will be reviewed through PsyCap. Therefore, this study aims to determine the impact of PsyCap on safety behavior of steam power plant contractor workers.

\section{METHODS}

The study conducted on May 2020 in steam power plant company, east java. This study using primary data and secondary data. Primary data is a form of questionnaires, while secondary data is a company's site safety statistic data. Population in this study is all workers in steam power plant company unit 7 and 8 which amount to 400 contractor workers. Respondents in this study based on calculation rule of thumb sampling from Averus and Pitono (2013) research and obtained 101 respondents of steam power plant contactor workers in unit 7 and 8.

Psychological capital in this study measured using a questionnaires adapted from Luthans, Youssef and Avolio (2007) which consist 24 item questions about self-efficacy, hope, optimism, and resiliency dimension of PsyCap. While safety behavior measurement using several questionnaires adapted from Vinodkumar and Bhasi (2010); Yagil and Luria (2010); Lu and Yang (2010); Clarke and Ward (2006); and Fernández-Muñiz, Montes-Peón and Vázquez-Ordás (2014). This questionnaire consists 23 item questions about safety compliance and safety participation. Form of this questionnaires using Likert scale from 1 (strongly disagree) to 4 (strongly agree).

Validity and reliability test conducted to determined that the question is valid or not for each item. This test was conducted on 30 respondents and to analyze using Pearson Product Moment correlation of SPSS software. Item of question is valid if the value more than $0.361(n=30)$. While to test reliability using Cronbach Alpha reliability test using SPSS software. Item of question is reliable if the value of coefficient more than 0.7 .

After testing the validity and reliability is structural equational modelling (SEM) test using AMOS software. SEM test carried out in two steps, measurement model or confirmatory factor analysis (CFA) and structural measurement or full model analysis. Confirmatory factor analysis refers to get the model of variable so from it can be used in the next step of analysis, structural measurement. While the full model analysis refers to get the influences model and whether or not the hypothesis is accepted. The model is fit if one of the absolute index, incremental index and parsimonious index of Goodness of Fit Index is fit. The construct indicator is valid if the value of standardized regression

Tabel 1. Characteristic Respondents

\begin{tabular}{|c|c|c|}
\hline Characteristic & Category & Amount \\
\hline \multirow{4}{*}{ Age } & $\leq 30$ у.о. & 40 \\
\hline & 31-39 у.о. & 30 \\
\hline & $40-49$ у.о. & 25 \\
\hline & $\geq 50$ у.о. & 6 \\
\hline \multirow{5}{*}{ Work Experience } & $\leq 5$ у.о. & 61 \\
\hline & $6-10$ у.о. & 21 \\
\hline & $11-15$ y.o. & 10 \\
\hline & $16-20$ у.о. & 3 \\
\hline & $\geq 20$ у.о. & 6 \\
\hline \multirow{2}{*}{ Work Accident } & Yes & 47 \\
\hline & No & 54 \\
\hline \multirow{2}{*}{$\begin{array}{l}\text { Frequency of } \\
\text { Work Accident }\end{array}$} & 1-5 during working & 34 \\
\hline & 6-10 during working & 13 \\
\hline \multirow{7}{*}{ Type of Accident } & Impacted & 13 \\
\hline & Scratched & 26 \\
\hline & Struct down & 1 \\
\hline & Got electric shock & 21 \\
\hline & Exposed of welding & 13 \\
\hline & Hit or knocked & 7 \\
\hline & Slip & 17 \\
\hline
\end{tabular}


weights more than 0.050 . Hypothesis will be accepted if the value of critical ratio in regression weights more than 1.96 or the value of probability less than 0.50 .

\section{RESULT}

The characteristic of the contractor workers in steam power plant company east java include age worker, work experience, accident experience, frequency of accident experience, and type of accident. The details of the respondents are shown in Tabel 1.

First step after distributing the questionnaires to 101 respondents is testing the validity and reliability. Validity test using Pearson Product Moment correlation with SPSS software, the value of all question items more than 0.361 . While the reliability test using Cronbach Alpha with SPSS software, the value of coefficient each variable more than 0,7 . Based on this value can be concluded that the question instrument is valid and reliable.

The SEM test conducted using AMOS software. The AMOS output of the PsyCap variable shows that RMSEA and AGFI criteria on absolute index of GOF have value 0.000 and 0.965 respectively; CFI and IF criteria on incremental index of GOF have value 1.000 and 1.006 respectively. From this value PsyCap variable be avowed fit. While the value of standardized regression weights, all items based on Tabel 2 more than 0.50 , so the indicator construct is valid.

Output result of the safety behavior variable shows that RMSEA and AGFI criteria on absolute index of GOF have value 0.070 and 0.955 respectively; CFI criteria on incremental index of

Tabel 2. Standardized Regression Weights PsyCap Variable

\begin{tabular}{cccc}
\hline & & & Estimate \\
\hline SE & $<---$ & PSYCAP & .679 \\
HP & $<---$ & PSYCAP & .781 \\
RS & $<---$ & PSYCAP & .523 \\
OP & $<---$ & PSYCAP & .595 \\
\hline
\end{tabular}

Tabel 3. Standardized Regression Weights Safety Behavior Variable

\begin{tabular}{cccc}
\hline & & & Estimate \\
\hline SC & $<---$ & SB & .791 \\
SP & $<---$ & SB & .620 \\
\hline
\end{tabular}

GOF have value 0.946; PGFI and PNFI criteria on parsimonious index of GOF have value 0.647 and 1.694. From this value safety behavior, be avowed fit. While the value of standardized regression weights value of all items based on Tabel 3 more than 0.50 , so the indicator construct is valid.

Based on the result of the confirmatory factor analysis test, entire variable model is fit and valid, so there is no indicator variable rejected. Structural analysis of the model conducted by combining all variables and the result as shown in Figure 2.

AMOS output of AGFI criteria on absolute index of GOF, CFI and IFI criteria on incremental index of GOF, and $\mathrm{NC}$ criteria on parsimonious index of GOF is fit. This result can be seen on Tabel 4. Result of hypothesis test there is one hypothesis that rejected, optimism has an influence on safety compliance. This is rejected because it has critical ratio value greater than 1.96 and probability value

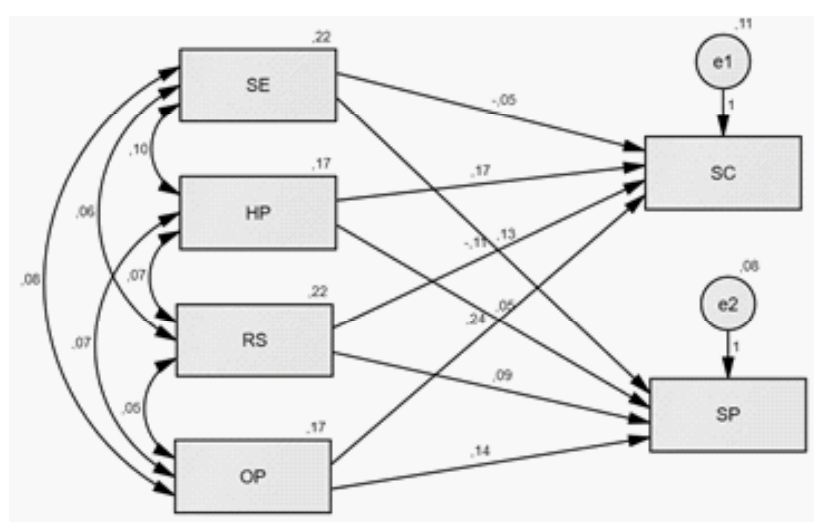

Figure 2. Full Model Fit

Table 4. Output GOF of Full Model

\begin{tabular}{cccc}
\hline $\begin{array}{c}\text { Goodness of } \\
\text { Fit Index }\end{array}$ & Cut of value & Result & Conclusion \\
\hline \multicolumn{4}{c}{ Absolute index } \\
\hline $\begin{array}{c}\text { Chi Square } \\
\text { Degree of } \\
\text { freedom }\end{array}$ & - & 17.711 & - \\
RMSEA & $\leq 0.80$ & 0.124 & No Fit \\
AGFI & $>0.80$ & 0.833 & Fit \\
\hline \multicolumn{5}{c}{ Incremental Index } \\
\hline CFI & $\geq 0.90$ & 0.906 & Fit \\
IFI & $\geq 0.90$ & 0.912 & Fit \\
\hline \multicolumn{5}{c}{ Parsimonious Index } & \\
\hline PNFI & $>0.50$ & 0.315 & No Fit \\
NC (CMIN/ & $<0.50$ & 0.403 & No Fit \\
DF) & $<5$ & 2.530 & Fit \\
\hline
\end{tabular}


Tabel 5. Output Regression Weights

\begin{tabular}{ccccc}
\hline $\begin{array}{c}\text { Dependent } \\
\text { Variable }\end{array}$ & & $\begin{array}{c}\text { Independent } \\
\text { Variable }\end{array}$ & C.R. & P \\
\hline SC & $<---$ & SE & -.544 & .586 \\
SC & $<---$ & HP & 1.698 & .089 \\
SC & $<---$ & RS & $-1, .71$ & .141 \\
SC & $<---$ & OP & 2.582 & .010 \\
SP & $<---$ & SE & 1.727 & .084 \\
SP & $<---$ & HP & .610 & .542 \\
SP & $<---$ & RS & 1.393 & .163 \\
SP & $<---$ & OP & 1.739 & .082 \\
\hline
\end{tabular}

Tabel 6. Direct Effect and Indirect Effect Between Dimensions

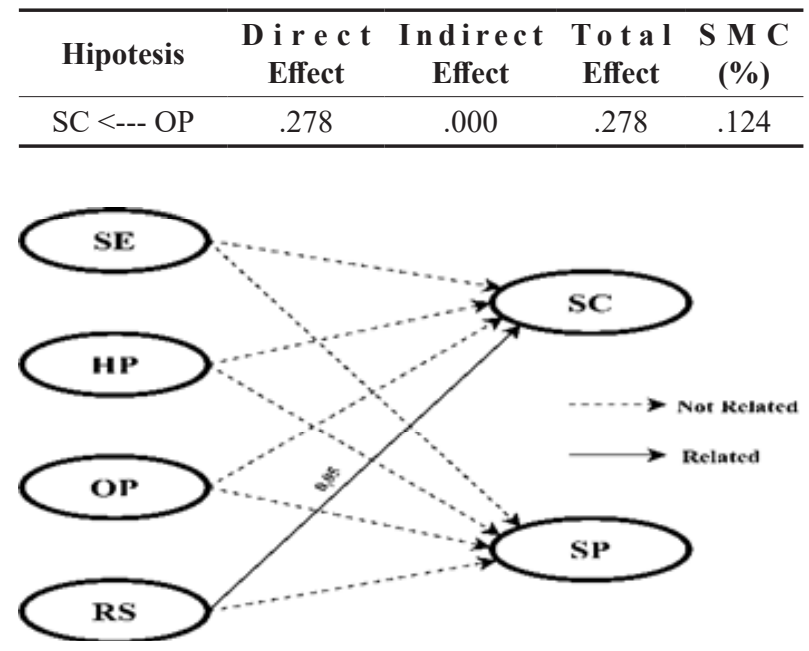

Figure 3. Final Structural Model and Influence of the Path

of less than 0.50. Hypothesis test result shows on tabel of regression weight such as Tabel 5. To make it easier to find out the effect of dimensions can be seen on Tabel 6 which shows the direct effect or indirect effect based in the result of influenced variable hypothesis or rejected of hypothesis null.

From tabel direct effect and direct effect, hypothesis test result easier be seen on Figure 2 which shows the final structural model and influence of the path. From the figure, optimism has a positive direct effect on safety compliance with coefficient value is 0.278 . Safety compliance variant value is 0.124 or $12.4 \%$ and explaining dimensions of self-efficacy (SE), hope (HP), resilience (RS), and optimism (OP).

\section{DISCUSSION}

Study result about impact of self-efficacy on safety behavior different from $\mathrm{He}$ et al. (2019).
This finding shows that self-efficacy significantly and positively influences on safety compliance and safety participation. This study assuming that feeling anda self-motivating with higher states have better feelings of work control and motivation to perform safely. Self-efficacy or self-confidence on PsyCap dimensions defined as an individual's belief in his ability to successfully achieve his goals (Lukito, 2018). Yuniarti (2016) explain that the importance of self-efficacy is a belief that the function as a importance continuity actions and persuade motivation, affective, and individual action. Self-efficacy found that have a positive impact on performance. Safety performance is once of the factors that play a role in safety (Rahadi, Anward and Tri Febriana, 2013). Only having safety knowledge without any internal persuade to take safety actions has a negative impact on safety performance (Rosalita, Ratmawati and Agustina, 2015). Curcuruto et al. (2015) worker participation on safety has a significant impact on organizational safety behavior and supported by the finding that safety behavior predicts accident rates and near miss reporting significantly for six month.

Hope in the dimension of Psychological Capital is defined as the energy that motivates a person to do work that focuses on goals related to life satisfaction, job satisfaction, performance, and motivation to cope with stressful events (Lukito, 2018). Hope has no influence on safety compliance and safety participation accordance with the result of research He et al. (2019) and the reason caused of social and cultural context. Workers face many challenges including high work-related pressures because of tight schedules, unstable employment, and high mobility, that makes them to take risks or use unsanctioned methods to complete their task more quickly. These actions might increase false hope, which could further increase the likelihood that they will violate safety regulations and avoid safety participation. Ye et al. (2019) hope entails not just the willpower toward a safety goal but also the way power to generate pathways for goal pursuits. Four dimensions of PsyCap would reduce the effect of safety related stress on safety behavior (Wang, Wang and Xia, 2018).

Resilience in the dimension of Psychological Capital is defined as a person's ability to recover from difficulties, failures, or irreversible changes (He et al., 2019). Resilience has no influence on safety compliance accordance with the results of research He et al. (2019), shows that the workers may also tend to rely on their own safety knowledge and 
experiences rather than learn new safety regulations and procedures, even when they encounter previously unseen safety situations or incidents and because it there is no relation between resilience and safety compliance. While the result of resilience has no influence on safety participation is contrast with the research result of $\mathrm{He}$ et al. (2019), shows that the occurred because the workers are temporary or seasonal workers and often face unforeseen problem such as skill learning, communication with others, and isolation from home. Yuniarti (2016) stated that resilience will be able to affect the welfare of workers if supported by good environmental and social conditions. If both of these not met, the resilience of workers only able to make the workers survive with the pressure received. Wang, Wang and Xia (2018) shows the positive influence of PsyCap on safety participation would reduce the negative influence of safety related stress on safety participation.

Optimism in the dimension of Psychological Capital is defined as the tendency to expect positive events in life that have a target to get what they want and believe in their ability to achieve a goal (Ihsani, 2018). Optimism has an influence on safety compliance and has no influence on safety participation contrast to the research $\mathrm{He}$ et al. (2019) stated that working in the same safety climate, pessimists may feel higher level of stress, which urges them to take more responsibility. While optimists may perceive lower levels of stress, which let them avoid from safety activity. Wang, Wang and Xia (2018) state that PsyCap would reduce the effect of safety related stress on safety behavior. Yuniarti (2016) in the world of work, optimism is related to satisfying things like workplace performance and work performance in various aspects of life such as education, sports, and politics. As for negative things that can be produced such as depression, physical illness and low performance in every scope of life.

Optimism requires controlling about possibility of events that will occur and divert the temporarily focus about what is happening now to the future with positive expectations. From it the workers have means necessary to meet safety requirements when facing challenges (safety compliance). An optimistic person tends to forgive what happened, properly evaluate the present, and look for opportunities. Optimistic workers tend to analyze the causes of obstacle, raises positive emotions and will make sensible choices to meet safety requirements. Therefore, they are more optimistic in dealing with stressful situations and more positive for finding solutions.
To increase optimism of power plant contractor workers in unit $7 \& 8$, can be doing accordance result study from Nandini (2016). This study giving appreciation of the results worker performance by conducting trainings or seminars to maintain workers optimism in the company. Awarding of this training accordance with the Undang-Undang RI (2003) concerning manpower where employers are responsible for improving and/or developing the competence of their workers through job training. Lisnawati, Juliani and Prasetyaningrum (2016) develops a way to increase optimism by training the ABCD method (Adversity, Belief, Consequence, Disputation, Energization). Participants in this training are given the opportunity to understand the meaning of optimism, carry out internal dialogue, recognize and evaluate the way of thinking that has been used $(\mathrm{ABC})$, recognize and understand the explanatory style used, learn to refute the unsupportive explanatory style ( D) causing affirming feelings and behaviors (E). In the other side, the study from Nurlitasari (2017) suggest by giving awarding "employee of the month". It is hoped that the workers will receive special pride and are motivated to maintain their achievements so that their performance is getting better.

\section{CONCLUSION}

Based on the research and analysis result, it can be concluded that the impact of PsyCap on safety behavior has a partial influence, which the result of model hypothesis test there is one hypothesis is rejected, optimism has no influence on safety compliance. Optimism dimension is the factors that has strongest impact on safety behavior, especially safety compliance of workers. While other dimensions (self-efficacy, hope, and resilience) has no impact on safety behavior, both safety compliance and safety participation dimensions. Future studies expected to add other variables that can influence the PsyCap impact on safety behavior such as using other type of questionnaires so the advantages and disadvantages of the questionnaire can be compared, add the number of respondents more than 101 workers so the models and assumptions related parameter hypothesis test more good result.

\section{ACKNOWLEDGEMENT}

The author would like grateful to all those with whom I have had the pleasure to work during related this research. This work would not have been possible without the support of steam power plant 
company in east java especially HSEC Department who have given permission and helped the author to retrieve data for supporting this article. The author also like to thank the Study Program of Safety and Health Engineering of Shipbuilding Institute of Polytechnic Surabaya as the author place of studying for giving knowledge.

\section{RFFERENCES}

Averus, A. and Pitono, A. (2013) 'Pengaruh Implementasi Kebijakan Pertambangan Terhadap Efektivitas Penanganan Kualitas Lingkungan Hidup Pada Dinas Pekerjaan Umum, Energi Dan Sumber Daya Mineral Kota Palu', Sosiohumaniora, 15(2), pp. 167-177.

Clarke, S. and Ward, K. (2006) 'The Role of Leader Influence Tactics and Safety Climate in Engaging Employees', Risk Analysis, 26(5), pp. 1175-1185.

Curcuruto, M. et al. (2015) 'The Role of Prosocial and Proactive Safety Behaviors in Predicting Safety Performance', Safety Science, 80(2015), pp. 317-323.

Fernández-Muñiz, B., Montes-Peón, J. M. and Vázquez-Ordás, C. J. (2014) 'Safety Leadership, Risk Management and Safety Performance in Spanish Firms', Safety Science, 70(December), pp. 295-307.

Griffin, M. A. and Hu, X. (2013) 'How Leaders Differentially Motivate Safety Compliance and Safety Participation: The Role of Monitoring, Inspiring, and Learning', Safety Science, 60(December), pp. 196-202.

He, C. et al. (2019) 'Impact of Psychological Capital on Construction Worker Safety Behavior: Communication Competence as a Mediator', Journal of Safety Research, 71(December), pp. 231-241.

Ihsani, A. N. (2018) Pengaruh Psychological Capital terhadap Komitmen Profesi pada Perawat. Thesis. Malang: Faculty of Psycology, Universitas Muhammadiyah Malang.

Lisnawati, D. K, Juliani, R. and Prasetyaningrum, J. (2016) 'Pelatihan Berpikir Optimis untuk Meningkatkan Orientasi Masa Depan Remaja Tuna Daksa', Jurnl Intervensi Psikologi, 8(2), pp. 250-262.

Lu, C.-S. and Yang, C.-S. (2010) 'Safety Leadership and Safety Behavior in Container Terminal Operations', Safety Science, 48(2), pp. 123134.
Luckyta, D. T. and Partiwi, S. G. (2012) 'Evaluasi dan Perancangan Sistem Manajemen Keselamatan dan Kesehatan Kerja (SMK3) dalam Rangka Perbaikan Safety Behaviour Pekerja (Studi Kasus : PT. X, Sidoarjo)', Jurnal Teknik ITS, 1(1), pp. 510-514.

Lukito, C. P. (2018) 'Hubungan Hope, SelfEfficacy, Resilience, Dan Optimism Dengan Entrepreneurial Intention Mahasiswa Fakultas Ekonomi Universitas Kristen Petra', Agora, 6(2).

Luthans, F., Youssef, C. M. and Avolio, B. J. (2007) Psychological Capital: Developing the Human Competitive Edge. New York: Oxford University Press.

Luthans, K. W., Luthans, B. C. and Chaffin, T. D. (2019) 'Refining Grit in Academic Performance: The Mediational Role of Psychological Capital', Journal of Management Education, 43(1), pp. 35-61.

Mehrdad, R. et al. (2014) 'Epidemiology of Occupational Accidents in Iran based on Social Security Organization Database', Iranian Red Crescent Medical Journal, 16(1), pp. 1-5.

Nandini, D. A. (2016) 'Kontribusi Optimisme Terhadap Kebahagiaan Pada Karyawan', Jurnal Ilmiah Psikologi Gunadarma, 9(2), pp. 187196.

Nurlitasari, N. (2017) Psychological Capital Pegawai Kontrak Ditinjau dari Jenis Kelamin di Dinas Cipta Karya dan Tata Kota Samarinda. Thesis. Semarang: Faculty of Science Education, Universitas Negeri Semarang.

OHS Body of Knowledge (2012) Models Causation: Safety. 1st edn, OHS Body of Knowledge. 1st edn. Victoria: Safety Institute of Australia.

Rahadi, F. D., Anward, H. H. and Tri Febriana, S. K. (2013) 'Hubungan Antara Persepsi Lingkungan Kerja Fisik dengan Perilaku Keselamatan Karyawan', Jurnal Ecopsy, 1(1), pp. 15-20.

Rosalita, N. A., Ratmawati, D. and Agustina, T. S. (2015) 'Mediasi Safety Knowledge dan Safety Motivation pada Pengaruh Safety Management Practices terhadap Safety Performance Karyawan Bagian Produksi PT.Petrokimia Gresik', Jurnal Manajemen Teori dan Terapan, 8(3), pp. 201215.

Shi, Y. et al. (2019) 'Impact Assessment of Reinforced Learning Methods on Construction Workers' Fall Risk Behavior Using Virtual Reality', Automation in Construction, 104(August), pp. 197-214. 
Undang-Undang RI (2003) 'Undang-Undang Republik Indonesia No.13 Tahun 2003 tentang Ketenagakerjaan'.

Vinodkumar, M. N. and Bhasi, M. (2010) 'Safety Management Practices and Safety Behaviour: Assessing the Mediating role of Safety Knowledge and Motivation', Accident Analysis and Prevention, 42,(6) pp. 2082-2093.

Wang, D., Wang, X. and Xia, N. (2018) 'How Safetyrelated Stress Affects Workers' Safety Behavior: The Moderating Role of Psychological Capital', Safety Science. 103 (March), pp. 247-259.

Yagil, D. and Luria, G. (2010) 'Friends in Need: The Protective Effect of Social Relationships Under
Low-Safety Climate', Group and Organization Management, 35(6), pp. 727-750.

Ye, X. et al. (2019) 'The Mediating Role of Psychological Capital between Perceived Management Commitment and Safety Behavior', Journal of Safety Research, 72 (February) pp. 29-40.

Yuniarti, A. (2016) 'Pengaruh Modal Psikologis dan Persepsi Gaya Kepemimpinan Transformasional terhadap Workplace Well Being', Tazkiya Journal of Psychology, 4(2), pp. 126-147. 